Abstract-The trophic ecology of 7 key species of Gadiformes, the silvery pout (Gadiculus argenteus), Mediterranean bigeye rockling (Gaidropsarus biscayensis), European hake (Merluccius merluccius), blue whiting (Micromesistius poutassou), Mediterranean ling (Molva macrophthalma), greater forkbeard (Phycis blennoides), and poor cod (Trisopterus minutus), in the western Mediterranean Sea was explored. A total of 3192 fish stomachs were examined during 2011-2017 to investigate ontogenetic shifts in diet, trophic interactions (both interspecific and intraspecific), and feeding strategies. The results from applying multivariate statistical techniques indicate that all investigated species, except the Mediterranean bigeye rockling and poor cod, underwent ontogenetic dietary shifts, increasing their trophic level with size. The studied species hold different trophic positions, from opportunistic (e.g., the Mediterranean bigeye rockling, with a trophic level of 3.51) to highly specialized piscivore behavior (e.g., the Mediterranean ling, with a trophic level of 4.47). These insights reveal 4 different feeding strategies among the co-occurring species and size classes in the study area, as well as the degree of dietary overlap. Such information on ecological patterns within a fish assemblage, including species interactions, is often requested by those who aim to implement ecosystem management. Therefore, these findings can be used to improve management of sustainable fisheries in this region.

Manuscript submitted 25 May 2020. Manuscript accepted 9 March 2021. Fish. Bull. 119:50-65 (2021).

Online publication date: 13 April 2021. doi: 10.7755/FB.119.1.7

The views and opinions expressed or implied in this article are those of the author (or authors) and do not necessarily reflect the position of the National Marine Fisheries Service, NOAA.

\title{
Ontogenetic shifts and feeding strategies of 7 key species of Gadiformes in the western Mediterranean Sea
}

\author{
Encarnación García-Rodríguez (contact author) ${ }^{1}$ \\ Miguel Vivas ${ }^{1}$ \\ José M. Bellido ${ }^{1}$ \\ Antonio Esteban' \\ María Ángeles Torres ${ }^{2}$ \\ Email address for contact author: encarnacion.garcia@ieo.es \\ ${ }^{1}$ Centro Oceanográfico de Murcia \\ Instituto Español de Oceanografía \\ Calle el Varadero 1 \\ San Pedro del Pinatar \\ 30740 Murcia, Spain \\ ${ }^{2}$ Centro Oceanográfico de Cádiz \\ Instituto Español de Oceanografía \\ Puerto Pesquero \\ Muelle de Levante $s / n$ \\ 11006 Cádiz, Spain
}

One of the most important aspects of analysis of trophic interactions is the study of trophic levels, understood as a hierarchical way of classifying organisms according to their feeding relationships within an ecosystem, contributing to knowledge about the ecological role of a species (Cochran et al., 2019). This knowledge is critical in investigating predator-prey interactions and is necessary for an ecosystem-based approach to fisheries management (Christensen, 1996; García et al., 2003). Additionally, feeding patterns offer useful insights about the long-term stability of marine ecosystems (Trites, 2003; McDonaldMadden et al., 2016).

In general, fish change their diets with size to optimize their energetic return (Scharf et al., 2000; Juanes et al., 2002). In addition, ontogenetic shifts can be considered a mechanism to avoid, or at least minimize, intraspecific competition by allowing exploitation of different food resources at each developmental stage
(Marrin, 1983; Castro and HernándezGarcía, 1995). More broadly, fish species have a wide range of strategies, on both intraspecific and interspecific levels, that result in and maintain resource partitioning (Madurell et al., 2008; Fanelli et al., 2009, 2013). Such strategies include not only food selection but also habitat selection and temporal segregation (Schoener, 1974). Hence, resource partitioning occurs when fish species are segregated into at least 1 of 3 niche dimensions. As a result, niche overlap is avoided and resource competition is minimized among fish species. This hypothesis is known as niche complementarity (Ebeling and Hixon, 1991) and assumes that a particular species, which overlaps with others in a given niche dimension, would separate along another dimension, maintaining resource partitioning. Describing and comparing these relationships, by using indices that reflect niche overlap or niche breadth, can help to explain 
feeding behaviors that range from generalist to specialist in nature (Silva et al., 2014).

This study aimed to investigate niche complementarity and co-occurrence of 7 fish species of Gadiformes in the western Mediterranean Sea off the coast of Spain. In particular, we analyzed ontogenetic shifts in diet, trophic interactions (both interspecific and intraspecific), feeding strategies, and the degree of dietary overlap among the studied species, to ascertain the ecological patterns of dietary interrelationships within the fish assemblage.

The selected gadiform species can inhabit depths greater than $1000 \mathrm{~m}$ (Fanelli et al., 2013) and play an important role in the middle of the food web (i.e., in both bottom-up and top-down controls) within marine ecosystems (Libralato et al., 2006), indicating that they feed on different trophic levels (Miller et al., 2010). They are prey for many other fish species (e.g., Preciado et al., 2008; Rodríguez-Cabello et al., 2014), and they occupy different substrates, ranging from sandy to rocky (Cohen et al., 1990).

In the Mediterranean Sea, the biology and behavior of many species of Gadiformes are well-documented (Morte et al., 2001, 2002), and they are important commercially and ecologically. For example, the European hake (Merluccius merluccius) is one of the most common representatives of this group, considering the amount of landings, and is currently experiencing overexploitation, with fishing mortality rates around 1.8-8.1 times higher than the assumed reference level of fishing mortality that would provide maximum sustainable yield (Colloca et al., 2013).

In the western Mediterranean Sea, studies of fish feeding habits usually focus on a few species and omit trophic interactions, information about which is essential for an effective implementation of an ecosystem approach to fisheries management (García et al., 2003). For instance, off the coast of Spain, Macpherson (1978a) studied agerelated seasonal feeding habits of blue whiting (Micromesistius poutassou) in the Gulf of Valencia and of silvery pout (Gadiculus argenteus) in the Catalan Sea. He also investigated the diet of the Mediterranean bigeye rockling (Gaidropsarus biscayensis) and Mediterranean ling (Molva macrophthalma) (Macpherson, 1978b, 1981). Bozzano et al. (1997) reported seasonal feeding habits of European hake in the Gulf of Lion off the coast of France, and Morte et al. (2001, 2002) analyzed the diet of poor cod (Trisopterus minutus) and greater forkbeard (Phycis blennoides) in the Gulf of Valencia. Unfortunately, none of these studies have investigated further interactions between species and fish assemblage.

Studies that address a broader geographic area and include ontogenetic shifts in diets of gadiform species, therefore, are scarce for the Mediterranean Sea off the coast of Spain, and it is necessary to fill this gap in knowledge as well as update current information. Additionally, the fish assemblage in the western Mediterranean Sea is currently facing problems of not only overfishing and biodiversity loss but also environmental pressures, such as the massive urbanization of coastlines, with increases in water pollution and decreases in sediments from principal rivers (e.g., Coll et al., 2010).
Catch quality is decreasing, resulting in landings with a higher proportion of low-value species and a higher ratio of small to large fish. Furthermore, in the case of some of the most damaging and commonly used gear, namely bottom trawls, discard rates of low-value species are high (Bellido et al. ${ }^{1}$; Paradinas et al., 2016). Under this scenario of overfishing and environmental pressures, a declining trend in the landed biomass of the commercial species of Gadiformes investigated in our study has been observed in the area $\left(\right.$ MAGRAMA $^{2}$; MAPAMA ${ }^{3} ;$ MAPA $^{4}$ ). Consequently, more local and updated data on intraspecific and interspecific interactions are needed to develop ecosystem models for an ecosystem-based approach to fisheries management (Christensen and Walters, 2004; Gascuel, 2005).

\section{Material and methods}

\section{Study area and sampling procedure}

We carried out our study in the Mediterranean Sea off the coast of Spain from Cape Palos to Cape Creus (Fig. 1). According to the General Fisheries Commission for the Mediterranean, this area is also known as geographical subarea 06 (GSA-06), and it extends along $808 \mathrm{~km}$ of coastline, with a total area of $30,119 \mathrm{~km}^{2}$ and depths of 40-800 $\mathrm{m}$. The study area is characterized by high biodiversity (García-Rodríguez et al., 2011) and oligotrophic conditions. Nevertheless, within the study area, certain zones (e.g., Ebro Delta) are exceptions because of their moderate levels of primary production (Estrada, 1996). The main fishery resources in this area are demersal and benthic organisms, such as fish species (Osteichthyes and Chondrichthyes) and invertebrates (mollusks and crustaceans). Some of the fish species, such as the bogue (Boops boops) or blotched picarel (Spicara maena), are heavily discarded, or they are used as bait, although they are an increasing component of landings, mainly in the bottom-trawl fishery (Bellido et al. ${ }^{1}$ ). Most of these species, including the European hake and blue whiting, both of the order Gadiformes, are fully exploited or overexploited (Coll et al., 2008; Cardinale, 2012, 2013; Coll et al., 2014; FAO, 2018).

\footnotetext{
${ }^{1}$ Bellido, J. M., A. Carbonell, M. T. García, and M. González. 2014. The obligation to land all catches-consequences for the Mediterranean: in-depth analysis, 46 p. Policy Dep. B: Struct. Cohes. Policies, Dir.-Gen. Intern. Policies, Eur. Parliam., Brussels, Belgium. [Available from website.]

2 MAGRAMA (Ministerio de Agricultura, Alimentación y Medio Ambiente). 2013-2015. Estadísticas pesqueras: Noviembre [2013-2015]. Minist. Agric. Aliment. Medio Ambiente, Madrid, Spain. [Available from website.]

${ }^{3}$ MAPAMA (Ministerio de Agricultura y Pesca, Alimentación y Medio Ambiente). 2016-2017. Estadísticas pesqueras: Noviembre [2016-2017]. Minist. Agric. Pesca Aliment. Medio Ambiente, Madrid, Spain. [Available from website.]

${ }^{4}$ MAPA (Ministerio de Agricultura, Pesca y Alimentación). 20182020. Estadísticas pesqueras: Noviembre [2018-2020]. Minist. Agric. Pesca Aliment., Madrid, Spain. [Available from website.]
} 


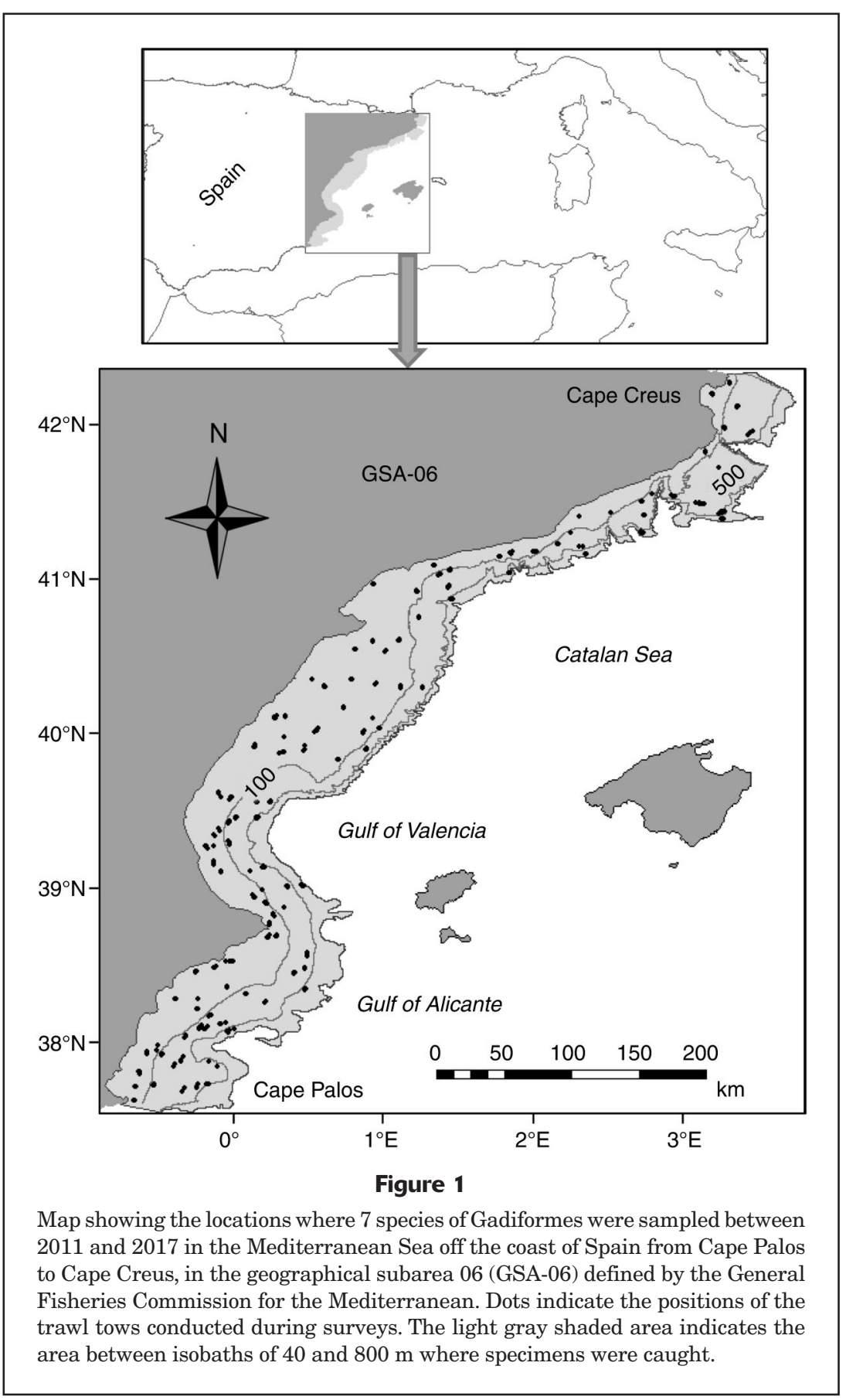

during daylight, from 0800 to 1800 , at depths of 40-730 m.

For this investigation, we selected the species of the order Gadiformes that were most abundant in the study area: the silvery pout, Mediterranean bigeye rockling, Mediterranean ling, European hake, blue whiting, greater forkbeard, and poor cod. During the survey cruises in the study period, the contents of 3192 stomachs were analyzed on board vessels (for details for these 7 species, see Table 1). After each trawl tow, 10 individuals of each of the studied species were randomly sampled from the haul. For all specimens examined, total length (TL) in millimeters, sex, and maturity stage were recorded according to MEDITS guidelines (Bertrand et al., 2002). Later, diet was assessed quantitatively by measuring the volume of stomach contents with a trophometer, a calibrated device that consists of several semicylinders of different sizes (Olaso, 1990). The use of this instrument is helpful on board oceanographic vessels because it allows a large number of stomachs to be examined in a relatively short period.

Once a stomach was opened, its contents were analyzed under a binocular microscope (Leica MZ6 ${ }^{5}$, Leica Microsystems, Wetzlar, Germany). Prey found in stomachs (prey items) were identified to the lowest possible taxon by using published guides (Zariquiey, 1968; Lombarte et al., 2006) and our own reference collection. The degrees of digestion of all prey items identified were also noted, as fresh, partially digested, or fully digested. The stomachs that contained any items presumably consumed in the net during fishing operations (i.e., stomachs from individuals of anglerfish species) were excluded from the analyses. The presence of skeletal remains and other hard body parts was also recorded. Stomach samples from

Stomach samples were collected from fish caught during bottom-trawl surveys conducted as part of the Mediterranean International Trawl Survey (MEDITS) program in GSA-06 in 2011-2017 (Bertrand et al., 2002). The surveys of this program take place yearly from May through June for the purpose of evaluating the demersal resources throughout the study area. The standard MEDITS sampling gear is a bottom trawl called the GOC 73, which has a net with a mesh size of $40 \mathrm{~mm}$ and a codend with a mesh size of $20 \mathrm{~mm}$. This gear is specifically designed for experimental fishing. A total of 604 trawl tows were carried out specimens that had regurgitated the contents of their stomachs were replaced with samples from individuals of a similar size class (García-Rodríguez et al., 2020). Following Robb (1992), the color and size of the gall bladder of European hake were used to determine if a specimen had an empty stomach or had regurgitated during the fishing operation.

\footnotetext{
${ }^{5}$ Mention of trade names or commercial companies is for identification purposes only and does not imply endorsement by the National Marine Fisheries Service, NOAA.
} 


\section{Table 1}

Summary information related to the 7 most abundant species of Gadiformes sampled in the western Mediterranean Sea between 2011 and 2017. For each species, the scientific and common names, depth range (in meters), number of stomachs for which contents were examined, and size range (total lengths in millimeters) are provided.

\begin{tabular}{llrrr}
\hline Scientific name & Common name & $\begin{array}{c}\text { Depth } \\
\text { range }\end{array}$ & $\begin{array}{c}\text { No. of } \\
\text { stomachs }\end{array}$ & $\begin{array}{c}\text { Size } \\
\text { range }\end{array}$ \\
\hline Gadiculus argenteus & Silvery pout & $109-647$ & 263 & $60-133$ \\
Gaidropsarus biscayensis & Mediterranean bigeye rockling & $59-634$ & 116 & $40-180$ \\
Molva macrophthalma & Mediterranean ling & $86-634$ & 164 & $83-740$ \\
Merluccius merluccius & European hake & $34-722$ & 1254 & $87-549$ \\
Micromesistius poutassou & Blue whiting & $76-722$ & 786 & $89-377$ \\
Phycis blennoides & Greater forkbeard & $53-728$ & 286 & $85-393$ \\
Trisopterus minutus & Poor cod & $36-352$ & 323 & $78-272$ \\
& & & & \\
\hline
\end{tabular}

\section{Dietary indices}

Three conventional dietary indices were calculated to provide quantitative information on diet compositions of the gadiform species investigated. A raw data set including prey species for each predator species is included in Supplementary Table 1. The first index used was frequency of occurrence (\%FO), defined as the number of stomachs containing a prey item compared with the total number of stomachs examined. The second index was the number index $(\% \mathrm{~N})$, defined as the number of individuals of a prey item compared with the total number of individual prey ingested. The third index calculated was the volume index $(\% \mathrm{~V})$, which represents the volume of a prey item compared with the total volume of ingested prey (Hyslop, 1980). Finally, the geometric index of importance (\%GII), which incorporates both \% FO and $\% \mathrm{~V}$, was used to avoid redundancy in the combination of mathematically dependent measures instead of other traditional indices (Tirasin and Jørgensen, 1999). It was computed as follows (Assis, 1996):

$$
\% G I I_{\mathrm{j}}=\left(\sum_{\mathrm{i}=1}^{\mathrm{n}} V_{\mathrm{i}}\right)_{\mathrm{j}} / n,
$$

where $V_{\mathrm{i}}=$ the value of the $i$ th relative measure of prey quantity for the prey group $j$ (in this case, $\left.V_{\mathrm{i}}=\% \mathrm{FO}+\% \mathrm{~V}\right)$, and

$n=$ the number of the relative measures of prey quantity used in the analysis (in this case, $n=2$, $\% \mathrm{FO}$ and $\% \mathrm{~V})$

Therefore, in this study, the \%GII was calculated as $(\% \mathrm{~V}+\% \mathrm{FO}) / 2$. Values for all indices are given as percentages.

\section{Ontogenetic shifts in diet}

Before identifying when ontogenetic shifts occur and establishing trophic groups based on different size classes, 10 major prey groups were identified according to taxonomic criteria and, in the case of fish species, habitat type criteria: small plankton; large plankton; Polychaeta; Cephalopoda; crab, lobster, and mantis shrimp species; shrimp species; Peracarida; demersal fish species; pelagic fish species; and benthopelagic fish species.

To investigate variation in a predator's diet according to size, trends in the volume index values of the most representative prey groups, mentioned in the previous paragraph, were plotted against fish length of predators to define the different categories that combine species and size class. We first compared both quantitative and qualitative methods. Results indicate similar outcomes for some species, such as the European hake or blue whiting, and outcomes were less realistic for those species with a small number of samples. Therefore, we decided to use a qualitative method based on a graphic technique that allows easy identification of the size at which the trend in the trophic strategy changed for each species studied. In the quantitative method, the number of size classes was estimated following the Sturges procedure (Scherrer, 1984), and in the qualitative method, the lengths were represented continuously at every millimeter along the $\mathrm{x}$-axis of graphs.

This graphic technique allows qualitative identification of the size at which a trophic shift occurred. We used this size for each gadiform species studied to divide size classes into large and small categories (sizes varied depending on the species; Table 2). In addition, size at first maturity was plotted with the aim of linking it with the size at which a trophic shift occurred. Sizes at first maturity for all the studied species were based on previously published data from studies in nearby areas (Biagi et al., 1992; Benghali et al., 2014; European Parliament and Council, 2019; Ismen et al., 2019).

\section{Trophic indices to describe feeding strategies}

To describe the degree of dietary diversity of a given species, we used niche breadth in accordance with Levins's 

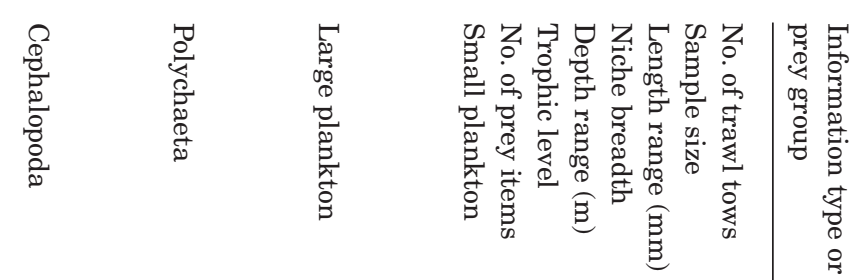

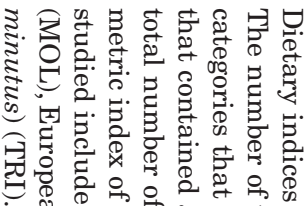

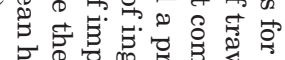

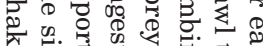

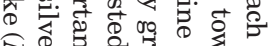

40

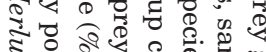

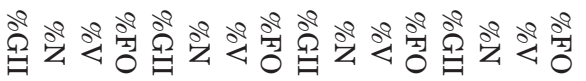

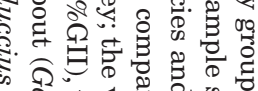

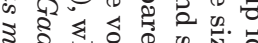

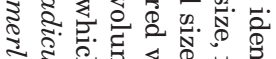

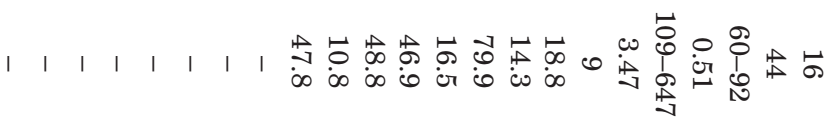

हิ हैं 今.

के कृ

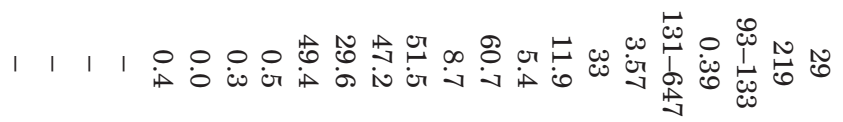

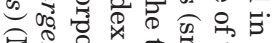

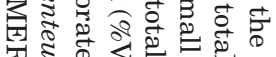

क ल क

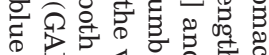

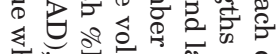

l l l l

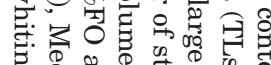

舟

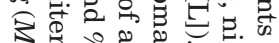

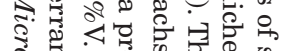

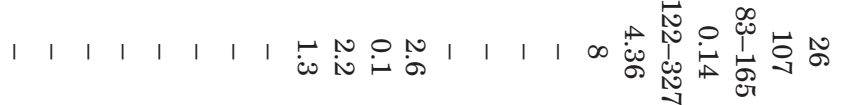

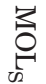

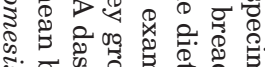

क.

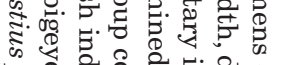

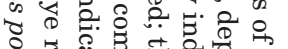

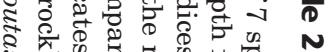

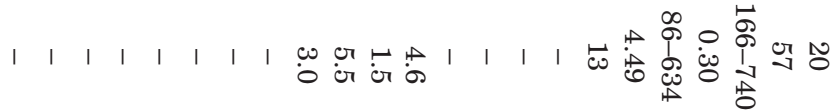

궁

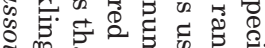

हैं

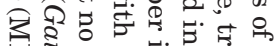

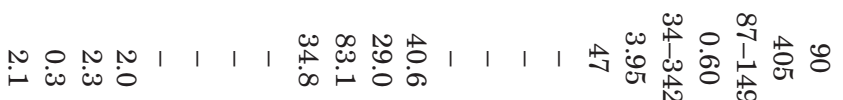

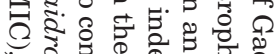

\% की

है

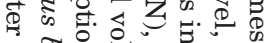

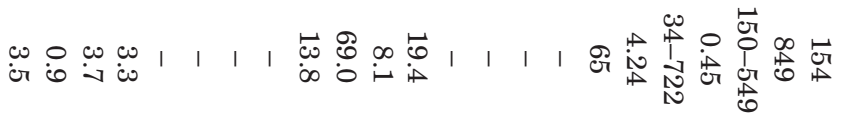

क्षे :

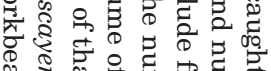

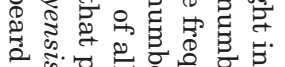

ชิ

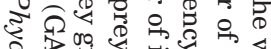

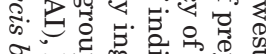

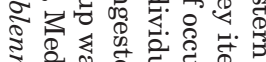

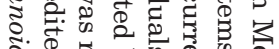

र

की

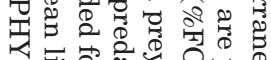

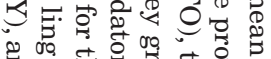

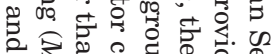

'大

ई ₹

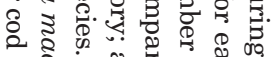

Э.

ब.

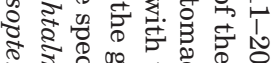

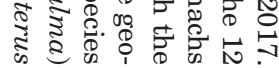




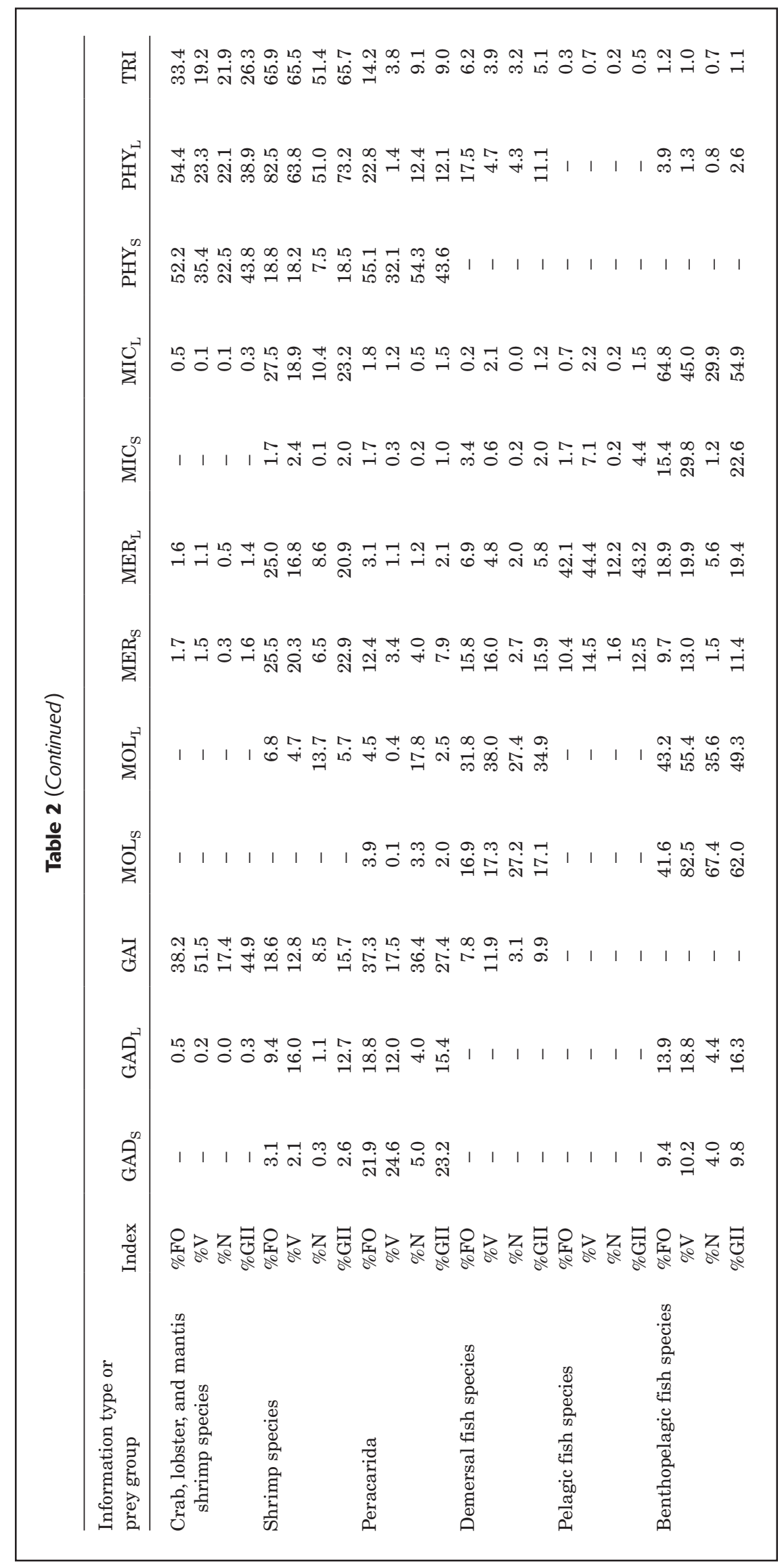


standardized index (Levins, 1968). This index ranges from 0 to 1 , with values close to 0 indicating a specialized diet and those close to 1 indicating more generalized feeding habits. This index was computed as follows:

$$
B_{\mathrm{i}}=\frac{1}{\mathrm{~N}-1} \times \frac{1}{\sum_{\mathrm{j}} p_{\mathrm{ij}}^{2}-1},
$$

where $B_{\mathrm{i}}=$ Levins's standardized index;

$p_{\mathrm{ij}}=$ the proportion of prey $j$ in the diet of predator $i$; and

$\mathrm{N}=$ the total number of prey groups.

The trophic niche overlap among the different studied species was estimated by using the simplified Morisita index (Morisita, 1959), which compares pairs of species with values ranging between 0.00 (no prey overlap) to 1.00 (full prey overlap) as follows:

$$
C_{\mathrm{jk}}=\frac{2 \sum p_{\mathrm{ij}} p_{\mathrm{jk}}}{\sum p_{\mathrm{ij}}^{2}+\sum p_{\mathrm{ik}}^{2}},
$$

where $C_{\mathrm{ik}}=$ the simplified Morisita index for predators $i$ and $k$, and

$p_{\mathrm{ij}}$ and $p_{\mathrm{kj}}=$ the proportions of predators $i$ and $k$ with prey $j$ in their stomachs.

The trophic level ( $\mathrm{T}$ ) was calculated by using the following formula developed by Christensen and Pauly (1992):

$$
T=1+\left(\Sigma D C_{\mathrm{ij}}\right)\left(N T_{\mathrm{j}}\right),
$$

where $D C_{\mathrm{ij}}=$ the proportion of prey $j$ in the diet of the predator $i$, and

$N T_{\mathrm{j}}=$ the trophic level of prey $j$.

Trophic levels of prey were determined empirically by using local information or, when this information was not available, by using the modeled area (Cortés, 1999; Ebert and Bizzarro, 2007; Fanelli et al., 2011; Jacobsen and Bennett, 2013; Corrales et al., 2015; for details on the species of prey for which these cited references were sources of local information on trophic levels, see Supplementary Table 2). In this study, the trophic level of each of the defined categories based on species and size class was first calculated by weighting its average biomass obtained during the surveys of the MEDITS program conducted in 2011-2017.

\section{Co-occurrence measures}

To analyze patterns of species associations related to food resource partitioning, we studied interspecific and intraspecific co-occurrence. Therefore, for the entire study period, we accounted for the abundance of all species and size classes estimated during surveys. The abundance of Mediterranean bigeye rockling was underestimated because of the low selectivity of the gear used to catch this small species. Therefore, this species was not included in the co-occurrence analysis. The Jaccard index $\left(S_{\mathrm{ij}}\right)$ was used to measure co-occurrence, as an expression of association between species (Jaccard, 1901):

$$
S_{\mathrm{ij}}=a /(a+b+c),
$$

where $a=$ the number of occasions in which both species or size classes are present;

$b=$ the number of occasions in which only one of the species is present; and

$\mathrm{c}=$ the number of occasions in which only the other species is present.

This index was calculated as the percentage of occasions that both species or size classes appeared in the same haul. In this study, the only hauls that were considered were those in which at least one of the species or size classes of each pair was present.

\section{Statistical analyses}

All data were standardized by using square-root transformation, and a Bray-Curtis similarity matrix was calculated. One-way analyses of similarity were performed to identify significant differences $(P<0.05)$ in trophic strategies between pairs of size classes (i.e., intraspecific competition). We used the software PRIMER 6 (PRIMER-e, Quest Research Ltd., Aukland, New Zealand) (Clarke and Gorley, 2006) to estimate global $R$ as a scaled measure of the separation between groups of samples, with values ranging from 0 (no differences) to 1 (completely different) (Clarke, 1993).

Similarity percentage analysis was applied to determine which prey groups contributed most to the dissimilarity in diet composition between such pairs. According to these results, new species-and-size categories were considered for further analyses. Finally, clustering methods and multidimensional scaling were used to analyze prey affinities and to discern feeding strategies that possibly were different between the studied species among size classes. All calculations were done by using PRIMER 6.

\section{Results}

\section{Diet composition and ontogenetic variation}

Overall, for all studied species as a group, the most common prey groups in terms of $\% \mathrm{~V}$ were large plankton; crab, lobster, and mantis shrimp species; shrimp species; and benthopelagic fish species. Large plankton, represented mainly by euphausiids, was the most common prey (mostly for silvery pout and blue whiting). In the case of decapod species, the red snapping shrimp (Alpheus glaber), green shrimp (Chlorotocus crassicornis), and angular crab (Goneplax rhomboides), all members of Pleocyemata, were the most abundant prey (mostly for Mediterranean bigeye rockling, poor cod, and greater forkbeard). Finally, benthopelagic fish species were primarily represented by blue whiting and myctophids as prey for studied species (mostly for Mediterranean ling and blue whiting) (Table 3). The raw data set 


\section{Table 3}

Volume index $(\% \mathrm{~V})$ values for prey groups identified in the stomach contents of specimens of 7 key species of Gadiformes caught in the western Mediterranean Sea during 2011-2017. The \%V value for a prey group represents the volume of that prey item compared with the total volume of all prey ingested by specimens of that species. The 7 species are the silvery pout (Gadiculus argenteus) (GAD), Mediterranean bigeye rockling (Gaidropsarus biscayensis) (GAI), Mediterrenean ling (Molva macrophtalma) (MOL), European hake (Merluccius merluccius) (MER), blue whiting (Micromesistius poutassou) (MIC), greater forkbeard (Phycis blennoides) (PHY), and poor cod (Trisopterus minutus) (TRI). A dash indicates that no consumption of that prey group was recorded for that species. An asterisk indicates the prey group with the highest $\% \mathrm{~V}$ value for each species. Information on niche breadth and the number of prey items is also reported.

\begin{tabular}{lccccccc}
\hline & \multicolumn{7}{c}{$\% \mathrm{~V}$} \\
\cline { 2 - 8 } Information type & GAD & GAI & MOL & MER & MIC & PHY & TRI \\
\hline Niche breadth & 0.34 & 0.34 & 0.17 & 0.38 & 0.26 & 0.16 & 0.14 \\
No. of prey items & 33 & 27 & 15 & 74 & 49 & 60 & 43 \\
Prey group & & & & & & & \\
Small plankton & 6.2 & 3.0 & - & 0.0 & - & 0.0 & - \\
Large plankton & $51.6^{*}$ & 1.6 & 0.9 & 12.0 & $40.3^{*}$ & 4.9 & 2.7 \\
Polychaeta & 0.3 & 1.8 & - & - & 1.9 & 0.4 & 0.4 \\
Cephalopoda & - & - & - & 3.7 & 0.8 & 1.0 & 2.8 \\
Crab, lobster, and mantis shrimp species & 0.1 & $51.5^{*}$ & - & 0.8 & 0.1 & 24.4 & 19.2 \\
Shrimp species & 12.4 & 12.8 & 2.5 & 14.4 & 13.2 & $60.6^{*}$ & $65.5^{*}$ \\
Peracarida & 11.1 & 17.5 & 0.3 & 1.0 & 0.9 & 2.8 & 3.8 \\
Demersal fish species & - & 11.9 & 22.6 & 6.6 & 1.7 & 4.3 & 3.9 \\
Pelagic fish species & - & - & - & $40.8^{*}$ & 3.6 & - & 0.7 \\
Benthopelagic fish species & 18.3 & - & $73.8^{*}$ & 20.6 & 37.4 & 1.6 & 1.0 \\
& & & & & & & \\
\hline
\end{tabular}

provided in Supplementary Table 1 documents in detail the different prey items found in stomachs and identified to the lowest taxonomic level in this study.

Regarding the ontogenetic variation in diet, for each of the studied species, the graph indicates trends in trophic strategies for 2 prey groups that were the opposite of the other, and this observation of different trends enabled us to establish a cutoff between the 2 size classes: the size at which a trophic shift occurred (Fig. 2). Only in the case of the silvery pout did the selected cutoff between size classes seem to be related to size at first maturity. For the Mediterranean bigeye rockling, no data are available on size at first maturity in the study area.

The results obtained for species and size classes indicate that silvery pout fed mainly on large plankton (\%GII $=51.2 \%, \% \mathrm{~V}=51.6 \%, \% \mathrm{FO}=50.9 \%)$, with Euphausia krohnii as the most predominant prey species. The diet of Mediterranean bigeye rockling was based primarily on crab, lobster, and mantis shrimp species $(\% \mathrm{GII}=44.9 \%, \quad \% \mathrm{~V}=51.5 \%, \quad \% \mathrm{FO}=38.2 \%)$ and species of Peracarida ( $\% \mathrm{GII}=27.4 \%, \% \mathrm{~V}=17.5 \%, \% \mathrm{FO}=37.3 \%)$, represented mainly by Calocaris macandreae and Lophogaster typicus, respectively. Benthopelagic fish species $(\% \mathrm{GII}=57.0 \%, \% \mathrm{~V}=73.8 \%, \% \mathrm{FO}=40.2 \%) \quad$ composed the major prey group for Mediterranean ling, for which the most commonly consumed prey was another species of Gadiformes, the silvery pout. Pelagic fish species $(\% \mathrm{GII}=29.0 \%, \% \mathrm{~V}=40.8 \%, \% \mathrm{FO}=17.2 \%)$ and large plankton $(\% \mathrm{GII}=15.1 \%, \% \mathrm{~V}=12.0 \%, \% \mathrm{FO}=18.3 \%)$ were the main prey groups for European hake, with European anchovy (Engraulis encrasicolus) and euphausiids being the most important of the consumed prey, respectively. Blue whiting fed mainly on large plankton $(\% \mathrm{GII}=39.3 \%$, $\% \mathrm{~V}=40.3 \%, \% \mathrm{FO}=38.3 \%)$ and benthopelagic fish species (\% $\mathrm{GII}=36.5 \%, \% \mathrm{~V}=37.4 \%, \% \mathrm{FO}=35.6 \%)$, of which euphausiids and the myctophid horned lanternfish (Ceratoscopelus maderensis) were the main prey, respectively. Similar prey items were also found in the diet of both greater forkbeard and poor cod: prey species were primarily shrimp species $(\% \mathrm{GII}=61.8 \%, \% \mathrm{~V}=60.6 \%$, and $\% \mathrm{FO}=62.9 \%$ and $\% \mathrm{GII}=65.7 \%, \% \mathrm{~V}=65.5 \%$, and $\% \mathrm{FO}=65.6 \%$, respectively), with red snapping shrimp as the most-represented prey.

Results of the one-way analyses of similarity indicate that there were significant differences in trophic composition between size classes $(P \leq 0.05)$ for all species studied except for the Mediterranean bigeye rockling and poor cod (Suppl. Table 3). Moreover, results of the similarity percentage analysis for the 5 species that had ontogenetic shifts identify the contribution of each prey item to the mean Bray-Curtis dissimilarity for each species. The average dissimilarity between size classes ranged from $41 \%$ for Mediterranean ling to $75 \%$ for European hake. These differences were a result of the distinct contribution of major prey groups to the stomach contents in specimens examined for each species (Suppl. Table 4). The major prey groups contributing the most to the ontogenetic shifts in the diet of silvery pout were large plankton and Peracarida, and for Mediterranean ling, the major prey groups were teleosts, such as demersal and benthopelagic fish species. Pelagic fish, large plankton, and shrimp species 


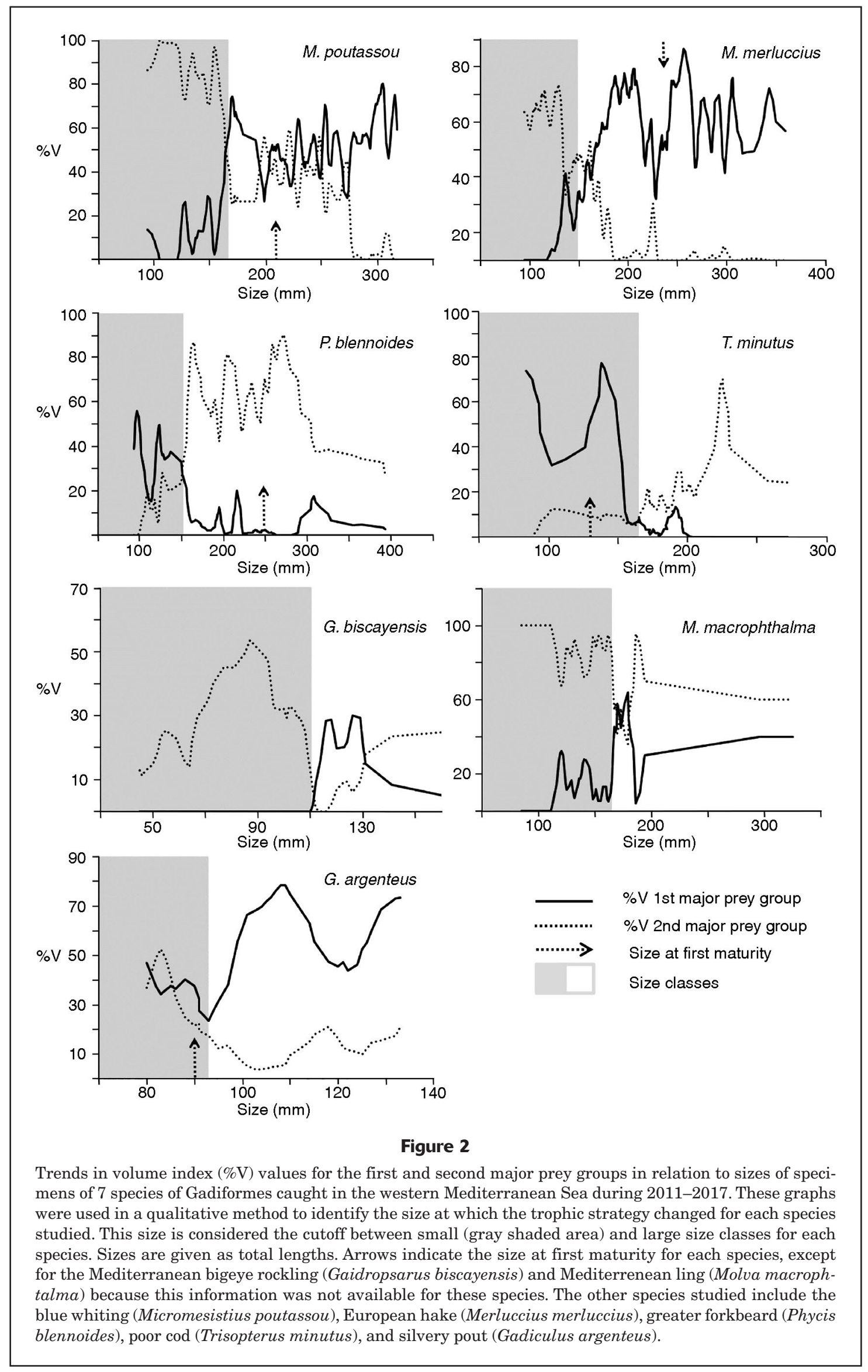


accounted for more than $60 \%$ of the diet of European hake. Species of large plankton and benthopelagic fish species contributed most to the diet of blue whiting (accounting for approximately $34 \%$ and $32 \%$ of the diet of this species, respectively); greater forkbeard fed mainly on shrimp species and species of Peracarida (Suppl. Table 4).

\section{Trophic ecology}

The trophic niche breadth index $\left(B_{\mathrm{i}}\right)$ was highest for European hake, Mediterrean bigeye rockling, and silvery pout (Table 3). Conversely, poor cod had the lowest $B_{\mathrm{i}}$ value, with a strong preference for red snapping shrimp $(\% \mathrm{~V}=44.1 \%)$, despite the high number of prey items (52) identified in its diet.

Niche breadth across the 12 categories that are based on species and size class was lowest $\left(B_{i}=0.136\right)$ for the small size class of Mediterranean ling; whereas, the small size class of greater forkbeard ranked the highest $\left(B_{\mathrm{i}}=0.636\right)$.

Simplified Morisita index values ranged from 0.00 (pair of the small size class of Mediterranean ling and -the small size class of greater forkbeard) to 1.00 (pair of the large size class of greater forkbeard and poor cod) (Table 4). Overall, niche overlap was highest between the small size class of greater forkbeard and poor cod, whose diet had a high proportion of shrimp species, represented principally by red snapping shrimp. The lowest values were found between the small size class of Mediterranean ling and poor cod as well as greater forkbeard.

The lowest and highest trophic levels were inferred for silvery pout (trophic level=3.51) and the large size class of Mediterranean ling (trophic level=4.49), respectively.
Within this range, only Mediterranean ling and the large size classes of European hake and blue whiting were determined to be at a trophic level $\geq 4$, representative of top predators (Table 2). For all species, with the exception of the greater forkbeard, which had no changes in trophic level with size, the large size classes were at a higher trophic level. The greatest increases in trophic level linked to an ontogenetic shift occurred in European hake (from 3.95 to 4.24 ) and blue whiting (from 3.98 to 4.21 ).

\section{Feeding strategies}

Four groups of predators were identified on the basis of different feeding strategies (Fig. 3). The first group consisted of species with strong preferences for decapods, such as the Mediterranean bigeye rockling, poor cod, and greater forkbeard. The red snapping shrimp was the dominant prey species for the large size class of greater forkbeard $(\% \mathrm{~V}=35.3 \%)$ and for poor cod $(\% \mathrm{~V}=44.1 \%)$, and Calocaris macandreae $(\% \mathrm{~V}=32.0 \%)$ and angular crab $(\% \mathrm{~V}=15.6 \%)$ were the main prey species for Mediterranean bigeye rockling and the small size class of greater forkbeard. The second group was composed of both size classes of Mediterranean ling, with silvery pout as the dominant prey (with $\% \mathrm{~V}$ values of $52.4 \%$ and $24.3 \%$ for the small and large size classes, respectively).

The third group identified was composed of both size classes of silvery pout, which had a high preference for large plankton, although in the case of small silvery pout, species of Peracarida were also consumed. In both size classes, euphausiids were the most common prey item (with \%V values of $46.8 \%$ and $36.8 \%$ for the small and large size classes, respectively).

\section{Table 4}

Simplified Morisita index values, which indicate trophic niche overlap between pairs of 12 categories of gadiform species for which stomach contents from specimens caught in the western Mediterranean Sea from 2011 through 2017 were examined. Categories combine species and size class (small [S] and large [L]; length ranges for size classes are provided in Table 2). Asterisks indicate extreme index values, defined as those $\geq 0.9$ and $<0.1$. The species studied were the silvery pout (Gadiculus argenteus) (GAD), Mediterranean bigeye rockling (Gaidropsarus biscayensis) (GAI), Mediterrenean ling (Molva macrophtalma) (MOL), European hake (Merluccius merluccius) (MER), blue whiting (Micromesistius poutassou) (MIC), greater forkbeard (Phycis blennoides) (PHY), and poor cod (Trisopterus minutus) (TRI).

\begin{tabular}{|c|c|c|c|c|c|c|c|c|c|c|c|c|}
\hline Category & $\mathrm{GAD}_{\mathrm{S}}$ & $\mathrm{GAD}_{\mathrm{L}}$ & GAI & $\mathrm{MOL}_{\mathrm{S}}$ & $\mathrm{MOL}_{\mathrm{L}}$ & $\mathrm{MER}_{\mathrm{S}}$ & $\mathrm{MER}_{\mathrm{L}}$ & $\mathrm{MIC}_{\mathrm{S}}$ & $\mathrm{MIC}_{\mathrm{L}}$ & $\mathrm{PHY}_{\mathrm{S}}$ & $\mathrm{PHY}_{\mathrm{L}}$ & TRI \\
\hline $\mathrm{GAD}_{\mathrm{S}}$ & 1.00 & & & & & & & & & & & \\
\hline $\mathrm{GAD}_{\mathrm{L}}$ & $0.92 *$ & 1.00 & & & & & & & & & & \\
\hline GAI & 0.18 & 0.17 & 1.00 & & & & & & & & & \\
\hline $\mathrm{MOL}_{\mathrm{S}}$ & 0.16 & 0.31 & $0.04 *$ & 1.00 & & & & & & & & \\
\hline $\mathrm{MOL}_{\mathrm{L}}$ & 0.17 & 0.31 & 0.13 & $0.90 *$ & 1.00 & & & & & & & \\
\hline $\mathrm{MER}_{\mathrm{S}}$ & 0.64 & 0.80 & 0.24 & 0.30 & 0.46 & 1.00 & & & & & & \\
\hline $\mathrm{MER}_{\mathrm{L}}$ & 0.22 & 0.36 & 0.12 & 0.35 & 0.38 & 0.67 & 1.00 & & & & & \\
\hline $\mathrm{MIC}_{\mathrm{S}}$ & 0.83 & $0.91^{*}$ & $0.04 *$ & 0.42 & 0.39 & 0.71 & 0.39 & 1.00 & & & & \\
\hline $\mathrm{MIC}_{\mathrm{L}}$ & 0.57 & 0.79 & 0.11 & 0.73 & 0.71 & 0.72 & 0.53 & 0.78 & 1.00 & & & \\
\hline $\mathrm{PHY}_{\mathrm{S}}$ & 0.46 & 0.43 & 0.88 & $0.00 *$ & $0.03 *$ & 0.37 & 0.17 & 0.21 & 0.24 & 1.00 & & \\
\hline $\mathrm{PHY}_{\mathrm{L}}$ & 0.10 & 0.33 & 0.53 & $0.03^{*}$ & 0.12 & 0.47 & 0.32 & 0.10 & 0.36 & 0.56 & 1.00 & \\
\hline TRI & $0.09 *$ & 0.32 & 0.49 & $0.03^{*}$ & 0.11 & 0.47 & 0.33 & $0.08 *$ & 0.35 & 0.54 & $1.00 *$ & 1.00 \\
\hline
\end{tabular}




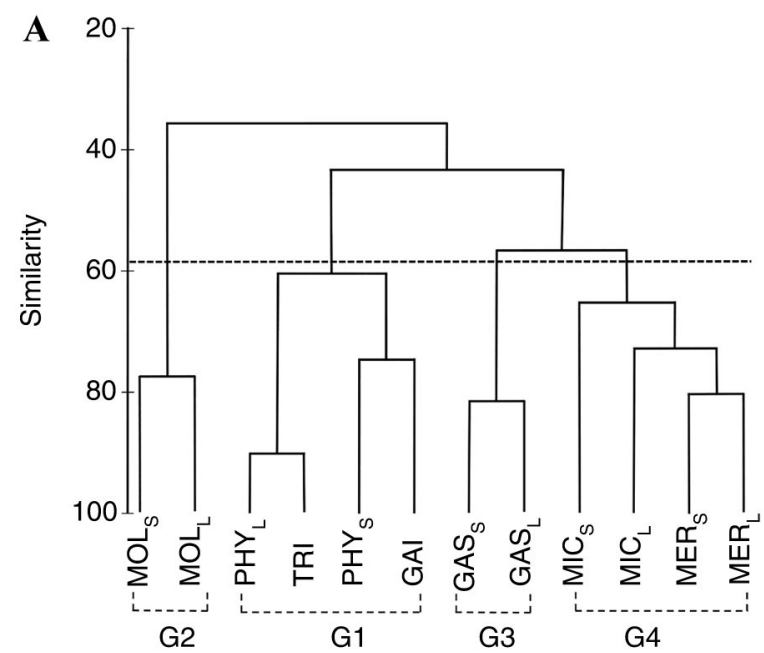

B

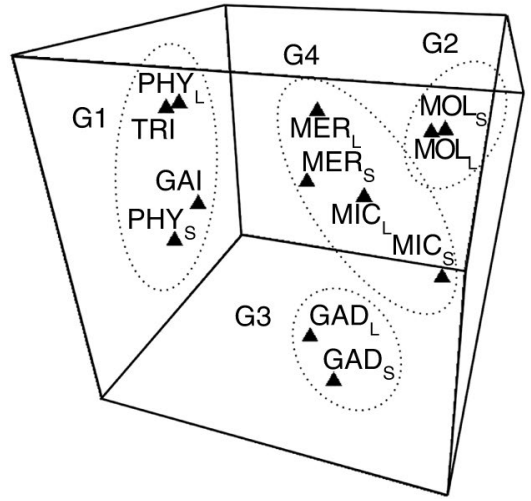

Figure 3

Multidimensional scaling ordination of stomach contents of specimens of 7 species of Gadiformes caught in the western Mediterranean Sea from 2011 through 2017. In the (A) 2-dimensional and (B) 3-dimensional plots, dashed lines indicate or dotted lines surround predator groups (G1, G2, G3, and G4) identified by using cluster analysis based on feeding strategies. Results are given for 12 categories that combine species and size class (small $[\mathrm{S}]$ and large $[\mathrm{L}]$; length ranges for size classes are provided in Table 2). The horizontal dashed line in panel A indicates the threshold similarity for group selection. The species studied include the Mediterrenean ling (Molva macrophtalma) (MOL), greater forkbeard (Phycis blennoides) (PHY), poor cod (Trisopterus minutus) (TRI), Mediterranean bigeye rockling (Gaidropsarus biscayensis) (GAI), silvery pout (Gadiculus argenteus) (GAD), blue whiting (Micromesistius poutassou) (MIC), and European hake (Merluccius merluccius) (MER)

The last group was represented by both size classes of blue whiting and European hake. The small size classes of both of these species preyed mostly on large plankton, with euphausiids as the most prevalent prey (with \%V values of $51.3 \%$ and $24.3 \%$, respectively). Benthopelagic fish species, namely the horned lanternfish $(\% \mathrm{~V}=19.3 \%)$ and the jewel lanternfish (Lampanyctus crocodilus) $(\% \mathrm{~V}=17.9 \%)$, were the main prey for the large size class of blue whiting. Pelagic fish species, such as the European anchovy (Engraulis encrasicolus) $(\% \mathrm{~V}=30.3 \%)$ and European pilchard (Sardina pilchardus) (\%V=9.9\%), were the species most widely consumed by the large size class of European hake.

\section{Co-occurrence and trophic overlap}

The highest percentages of co-occurrence were found for the associations of European hake with poor cod $(75.8 \%)$ and blue whiting with greater forkbeard (64.1\%) (Fig. 4). Conversely, the lowest values of co-occurrence were observed for Mediterranean ling with poor cod (11.3\%) and European hake with Mediterranean ling (14.1\%). These results, together with analysis of trophic levels, indicate a high niche overlap between silvery pout and blue whiting and a low degree of overlap between Mediterranean ling and poor cod.

All species had an intraspecific trophic overlap greater than 0.50. Greater forkbeard had the lowest value (0.56), and silvery pout had the highest value (0.92). On the other hand, low co-occurrence was found for both blue whiting and Mediterranean ling (0.16 and 0.20, respectively), and high values of co-occurrence were found for European hake, greater forkbeard, and silvery pout $(0.77,0.69$, and 0.68 , respectively).

\section{Discussion}

Our comprehensive study of feeding habits and trophic relationships among 7 fish species of the order Gadiformes that are important to fisheries in the western Mediterranean Sea explored ecological patterns such as those of ontogenetic variation in diet or trophic and spatial segregation of species. The results of this work can inform efforts to improve management of resource partitioning within and among these species in a broad geographic area (i.e., the entire GSA-06).

Our data indicate that the species studied are structured into 4 major guilds based on their feeding habits. The first group comprises the Mediterranean bigeye rockling, poor cod, and greater forkbeard. These species occupy medium-high positions within the food web. Their diets have previously been reported to consist of decapods and other small crustaceans, for example, for poor cod or greater forkbeard in the Catalan Sea (Macpherson, 1978b), in the Gulf of Valencia (Morte et al., 2001, 2002), and in the Adriatic Sea (Dulčić and Dulčić, 2004). However, for Mediterranean bigeye rockling, our results differ from those of Macpherson (1978b), who identified Eusergestes arcticus and northern krill (Meganyctiphanes norvegica) as the predominant prey. Our results indicate that Calocaris macandrae was the primary prey species of Mediterranean bigeye rockling, and it is worth noting that this species was also found to be cannibalistic. These differences may be related to the 38-year gap between the 2 studies or are possibly a result of the fact that our sampling did not explore seasonal dietary 


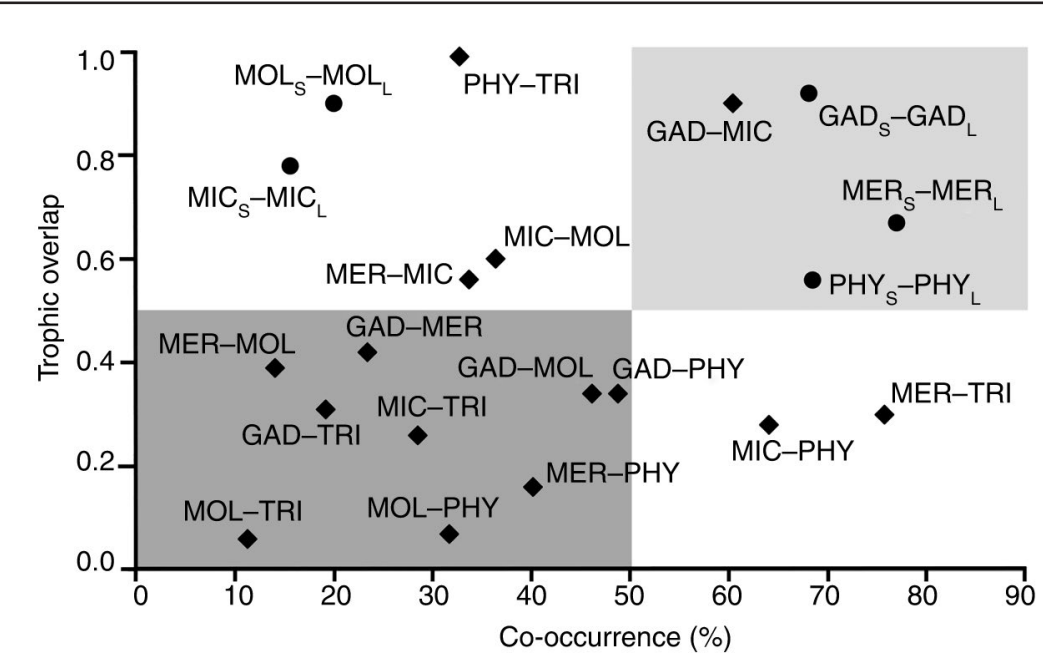

Figure 4

Level of trophic overlap and percentage of co-occurrence for pairs of 12 categories of 7 gadiform species for which stomach contents from specimens caught in the western Mediterranean Sea during 2011-2017 were examined. The 12 categories combine species and size class (small [S] and large [L]; length ranges for size classes are provided in Table 2). Diamonds and circles indicate interspecific and intraspecific interactions, respectively. Pairs in the dark gray area had low niche overlap, and pairs in the light gray area had high niche overlap. The species studied include the silvery pout (Gadiculus argenteus) (GAD), Mediterranean bigeye rockling (Gaidropsarus biscayensis) (GAI), European hake (Merluccius merluccius) (MER), blue whiting (Micromesistius poutassou) (MIC), Mediterrenean ling (Molva macrophtalma) (MOL), greater forkbeard (Phycis blennoides) (PHY), and poor cod (Trisopterus minutus) (TRI).

such as euphausiids and shrimp species, confirming the feeding habit observations previously reported by Macpherson (1978a) for silvery pout in the western Mediterranean. Therefore, these results indicate that the silvery pout consumes a broad range of prey items, a diet characteristic of a generalist feeder. We also found ontogenetic variation for this species, with it becoming a more specialized predator as its trophic level increased. This result contrasts with the findings reported by Macpherson (1978a), who observed no clear link between diet and size for the silvery pout.

The last of the 4 feeding guilds we identified is represented by both size classes of European hake and blue whiting, which occupy a position high in the food web. As has been observed for Mediterranean ling, both the European hake and blue whiting seem to be primarily piscivorous, although their diets in addition include shrimp species (Pasiphaea spp.) and large plankton, particularly euphausiids (e.g., northern krill). For European hake, our findings are consistent with those of other studies from the western Mediterranean Sea (Bozzano et al., 1997; Cartes et al., 2009). However, slight differences were found when comparing the diets of fish sampled in waters

changes; we restricted our study to the spring, when the MEDITS is carried out. This high degree of predation on decapod crustaceans by greater forkbeard and poor cod is indicative of a narrow trophic niche breadth compared with that of the Mediterranean bigeye rockling, which was found to have more generalist feeding habits. Moreover, and in agreement with results reported by Morte et al. (2002), an ontogenetic shift occurred in the diet of greater forkbeard in our study, but our findings differ from those of Morte et al. (2001) for poor cod in that no ontogenetic dietary shift was found.

The second group consists of both size classes of Mediterranean ling, and this species had the highest trophic levels among the 7 species studied. The diet of this species is primarily composed of benthopelagic and demersal fishes, such as the silvery pout and poor cod. This evidence indicates that the Mediterranean ling occupies a narrow trophic niche, a finding that is in agreement with the results previously reported by Macpherson (1981) for the same study area.

A third trophically distinct group is composed of both size classes of silvery pout, which is the only species primarily exploiting resources at the base of the food web, playing an important role in the energy flow from the lowest levels to the top of the food web. The majority of the diet of the silvery pout consists of a variety of small crustaceans, of the North Atlantic Ocean and the eastern Mediterranean Sea, where crustaceans were relatively less important and mackerels play the role reserved for sardines in our study area (Guichet, 1995; Velasco and Olaso, 1998; Philips, 2012). Regarding blue whiting, our results agree with those reported by Olaso and Rodríguez-Marín ${ }^{6}$, Velasco et al. ${ }^{7}$, and Gutiérrez-Zabala et al. ${ }^{8}$ for this species in the Cantabrian Sea off the northern coast of Spain, but they contrast with the findings of Preciado et al. (2002) for blue whiting in the south of Galicia in the northwest of Spain and of Torres et al. (2013) for this species in the Gulf of Cadiz off the southern coasts of Portugal and

\footnotetext{
${ }^{6}$ Olaso, I., and E. Rodríguez-Marín. 1995. Alimentación de veinte especies de peces demersales pertenecientes a la división VIIIc del ICES. Otoño 1991. Inst. Esp. Oceanogr., Inf. Téc. 157, 56 p. [In Spanish.] [Available from Inst. Esp. Oceanogr., Calle Corazón María 8, 28002 Madrid, Spain.]

${ }^{7}$ Velasco, F., I. Olaso, and F. de la Gándara. 1996. Alimentación de veintidós especies de peces demersales de la división VIIIc del ICES. Otoños de 1992 y 1993. Inst. Esp. Oceanogr., Inf. Téc. 164, 62 p. [In Spanish.] [Available from Inst. Esp. Oceanogr., Calle Corazón María 8, 28002 Madrid, Spain.]

${ }^{8}$ Gutiérrez-Zabala, J. L., F. Velasco, and I. Olaso. 2001. Alimentación de veintiuna especies de peces demersales de la división VIIIc del CIEM. Otoños de 1994 y 1995. Inst. Esp. Oceanogr., Datos Resúm. 16, 61 p. [In Spanish.] [Available from Inst. Esp. Oceanogr., Calle Corazón María 8, 28002 Madrid, Spain.]
} 
Spain. In these latter 2 papers, a higher dependency on crustaceans, particularly euphausiids, was reported.

As far as differences in diet compositions between the European hake and blue whiting in our study are concerned, the European hake was found to prey mainly on pelagic fish species (i.e., sardines and European anchovy), as well as on benthopelagic (e.g., blue whiting) and demersal (e.g., poor cod) fish species, and the blue whiting was found to feed mainly on benthopelagic fish species (e.g., the horned lanternfish and jewel lanternfish). This ability of European hake to prey on different groups resulted in the European hake occupying the broadest trophic niche of all the species studied. Hence, in relation to ontogenetic shifts in diet, both species are characterized by a decreasing consumption of euphausiids and an increasing proportion of fish species with size. All of these results agree with those reported by Bozzano et al. (1997) for work in the Gulf of Lion and by Cartes et al. (2009) for a study in the Balearic Islands, a small archipelago off the northeastern coast of Spain.

Results for examination of niche breadth indicate a pattern that relates size class to niche breadth. The small size classes had a broader trophic niche than that of the large size classes, for all species studied except the Mediterranean ling, with ontogenetic growth leading to greater specialization in these species. In contrast, the Mediterranean ling is a specialist piscivorous species, the larger size of the specimens of which, in comparison to the size of individuals of other species studied, allowed it to have access to a greater number of potential prey in its diet. Therefore, its trophic niche increased with the ontogenetic development of specimens. Our findings for the Mediterranean ling indicate a relationship between size class and trophic level, with the trophic level being lower in the small size classes and increasing after the ontogenetic shift. This difference in the trophic level between size classes was greater for those species located higher in the trophic web (e.g., the European hake, blue whiting, and Mediterranean ling).

We found that the studied species of Gadiformes exploit food resources at different trophic levels of the food web, indicating ontogenetic shifts in diet and resource partitioning. The silvery pout, for example, plays a role closer to that of a primary consumer, with the specimens that composed the small size class being those with the lowest trophic level. Fish species that play a similar role within the food web include species of Gobius, Mullus, Symphodus, and Diplodus, according to Karachle and Stergiou (2017). An intermediate trophic position is occupied by the poor cod, greater forkbeard, Mediterranean bigeye rockling, and the small size classes of blue whiting and European hake, as well as of the blackmouth catshark (Galeus melastomus) and species of Serranus, Pagellus, and Chelidonichthys (Karachle and Stergiou, 2017). Large specimens of European hake and blue whiting have a position in the upper part of the food web, along with species of Raja and Scorpaena (Karachle and Stergiou, 2017). Finally, the Mediterranean ling, primarily a piscivorous species, is in the highest trophic level, similar to other piscivorous species such as the common dentex (Dentex dentex), greater amberjack (Seriola dumerili), bluefin tuna (Thunnus thynnus), and John dory (Zeus faber) (Karachle and Stergiou, 2017).

If an ecosystem is structured in accordance with the hypothesis of niche complementarity (Ebeling and Hixon, 1991), on the basis of the distribution and diet of the species involved, the structure should have consistently low niche overlap such that the coexistence of similar species occurs because of differences in resource use (Pianka, 1973; Schoener, 1974). We investigated the dietary overlap of coexisting species for which a partitioning of trophic resources was found among species and size classes. This finding indicates that the 7 species studied occupy different trophic positions, ranging from a generalized feeding behavior to specialized piscivorous habits. These results might complement those reported by Macpherson (1978a) and Morte et al. (2001, 2002), who investigated changes with season and depth, respectively, in the diets of blue whiting, silvery pout, poor cod, and greater forkbeard. They related availability of prey to diet depending on the season. Moreover, differences in the patterns of species distribution reduce niche overlap even further.

Only 3 pairs of species had a co-occurrence greater than $50 \%$, with the pairs of blue whiting and greater forkbeard and of European hake and poor cod having by far the highest values of spatial overlap but correspondingly low values of trophic overlap. This distributional and trophic strategy minimizes interspecific competition. Cases in point are the Mediterranean ling and blue whiting, which may avoid intraspecific competition through this mechanism. Only the species pair of silvery pout and blue whiting had high values for both indices, indicating strong competition for resources between these 2 species.

For 5 of the 7 species, excluding the Mediterranean bigeye rockling and poor cod, ontogenetic shifts in diet were found, shifts that allowed them to occupy several niches or subniches simultaneously (Deselle et al., 1978; Keast, 1978). These ontogenetic shifts were associated with an increase in inferred trophic levels for all the species, contributing to increasing segregation between size classes (Pauly et al., 2001). Although the size classes described in this study are related to shifts in trophic strategies, intraspecific trophic overlap was observed for those 5 species that had ontogenetic shifts in their diets, and the intraspecific overlap was generally higher than the interspecific overlap. This result is in line with that of Bergstad (1991), who found that the effects of competitive interactions are more likely to occur between size classes of the same species than between different species.

Of those 5 species, the greater forkbeard, European hake, and silvery pout had high co-occurrence that involved strong competition for food resources, resulting in high intraspecific trophic overlap. An important aspect of this kind of competition is cannibalism, which was found in European hake, and this result is in agreement with findings reported by Macpherson (1979), Bozzano (1997), 
and Cartes et al. (2009) for studies in the western Mediterranean Sea, as well as in nearby regions of the Atlantic Ocean (Torres et al., 2013; López-López et al., 2015).

\section{Acknowledgments}

The authors express their gratitude to all the people who worked on surveys of the MEDITS program. Data collection was co-funded by the European Union (EU) through the European Maritime and Fisheries Fund within the national program for the collection, management, and use of data in the fisheries sector and support for scientific advice regarding the EU Common Fisheries Policy.

\section{Literature cited}

Assis, C. A.

1996. A generalized index for stomach contents analysis in fish. Sci. Mar. 60:385-389.

Benghali, S. M., S. Mouffok, A. Kherraz, and Z. Boutiba.

2014. Reproductive biology and growth of greater forkbeard Phycis blennoides (Brünnich, 1768) in Western Algerian coasts (Osteichthyes, Gadidae). J. Biol. Environ. Sci. 4(6):389-398.

Bergstad, O. A.

1991. Distribution and trophic ecology of some gadoid fish of the Norwegian deep. Sarsia 75:315-325. Crossref

Bertrand, J. A., L. Gil de Sola, C. Papaconstantinou, G. Relini, and

A. Souplet.

2002. The general specifications of the MEDITS surveys. Sci. Mar. 66(S2):9-17. Crossref

Biagi, F., S. de Ranieri, and C. Viva.

1992. Recruitment, length at first maturity and feeding of poor-cod, Trisopterus minutus capelanus, in the northern Tyrrhenian Sea. Boll. Zool. 59(1):87-93. Crossref

Bozzano, A., L. Recasens, and P. Sartor.

1997. Diet of the European hake Merluccius merluccius (Pisces: Merluciidae) in the Western Mediterranean (Gulf of Lions). Sci. Mar. 61:1-8.

Cardinale, M., G.-C. Osio, and A. Charef (eds.).

2012. Report of the scientific, technical and economic committee for fisheries on assessment of Mediterranean Sea stocks-part 1 (STECF 12-19), 494 p. JRC Sci. Policy Rep. JRC 76735. Publ. Off. Eur. Union, Luxembourg, Luxembourg. [Available from website.]

2013. Report of the scientific, technical and economic committee for fisheries (STECF) 2012 assessment of Mediterranean Sea stocks-part 2 (STECF 13-05), 618 p. JRC Sci. Policy Rep. JRC 81592. Publ. Off. Eur. Union, Luxembourg, Luxembourg. [Available from website.]

Cartes, J. E., M. Hidalgo, V. Papiol, E. Massutí, and J. Moranta. 2009. Changes in the diet and feeding of the hake Merluccius merluccius in the shelf-break of Balearic Islands: influence of the mesopelagic-boundary community. Deep-Sea Res., I 56:344-365. Crossref

Castro, J. J., and V. Hernández-García.

1995. Ontogenetic changes in mouth structures, foraging behaviour and habitat use of Scomber japonicus and Illex coindetii. Sci. Mar. 59:347-355.

Christensen, V.

1996. Managing fisheries involving predator and prey species. Rev. Fish Biol. Fish. 6:417-442. Crossref
Christensen, V., and D. Pauly.

1992. ECOPATH II-a software for balancing steady-state ecosystem models and calculating network characteristics. Ecol. Model. 61:169-185. Crossref

Christensen, V., and C. J. Walters.

2004. Ecopath with Ecosim: methods, capabilities and limitations. Ecol. Model. 172:109-139. Crossref

Clarke, K. R.

1993. Non-parametric multivariate analyses of changes in community structure. Aust. J. Ecol. 18:117-143. Crossref

Clarke, K. R., and R. N. Gorley.

2006. PRIMER v6: user manual/tutorial, 190 p. PRIMER-E, Plymouth, UK.

Cochran, J. K., H. J. Bokuniewicz, and P. L. Yager (eds.).

2019. Encyclopedia of ocean sciences, 3rd ed., 4306 p. Academic Press, London.

Cohen, D. M., T. Inada, T. Iwamoto, and N. Scialabba.

1990. FAO species catalogue. Vol. 10. Gadiform fishes of the world (Order Gadiformes). An annotated and illustrated catalogue of cods, hakes, grenadiers and other gadiform fishes known to date. FAO Fish. Synop. 125, 442 p. FAO, Rome.

Coll, M., I. Palomera, S. Tudela, and M. Dowd.

2008. Food-web dynamics in the South Catalan Sea ecosystem (NW Mediterranean) for 1978-2003. Ecol. Model. 217:95-116. Crossref

Coll, M., C. Piroddi, J. Steenbeek, K. Kaschner, F. B. R. Lasram, J. Aguzzi, E. Ballesteros, C. N. Bianchi, J. Corbera, T. Dailianis, et al.

2010. The biodiversity of the Mediterranean Sea: estimates, patterns, and threats. PLoS ONE 5(8):e11842. Crossref

Coll, M., M. Carreras, M. J. Cornax, E. Massutí, E. Morote, X. Pastor, A. Quetglas, R. Sáez, L. Silva, I. Sobrino, et al.

2014. Closer to reality: reconstructing total removals in mixed fisheries from Southern Europe. Fish. Res. 154:179-194. Crossref

Colloca, F., M. Cardinale, F. Maynou, M. Giannoulaki, G. Scarcella, K. Jenko, J. M. Bellido, and F. Fiorentino.

2013. Rebuilding Mediterranean fisheries: a new paradigm for ecological sustainability. Fish Fish. 14:89-109. Crossref

Corrales, X., M. Coll, S. Tecchio, J. M. Bellido, A. M. Fernández, and I. Palomera.

2015. Ecosystem structure and fishing impacts in the northwestern Mediterranean Sea using a food web model within a comparative approach. J. Mar. Syst. 148:183-199. Crossref

Cortés, E.

1999. Standardized diet compositions and trophic levels of sharks. ICES J. Mar. Sci. 56:707-717. Crossref

Deselle, W. J., M. A. Poirrier, J. S. Rogers, and R. C. Cashner.

1978. A discriminant functions analysis of sunfish (Lepomis) food habits and feeding niche segregation in the Lake Pontchartrain, Louisiana estuary. Trans. Am. Fish. Soc. 107:713-719. Crossref

Dulčić, J., and Z. Dulčić.

2004. Feeding habits of the Mediterranean poor cod Trisopterus minutus capelanus (Lacépède) (Pisces: Gadidae) from the eastern central Adriatic. Ann. Ser. Hist. Nat. 14:189-196.

Ebeling, A. W., and M. A. Hixon.

1991. Tropical and temperate reef fishes comparison of community structures. In The ecology of fishes on coral reefs (P. F. Sale, ed.), p. 509-563. Academic Press, San Diego, CA.

Ebert, D. A., and J. J. Bizzarro.

2007. Standardized diet compositions and trophic levels of skates (Chondrichthyes: Rajiformes: Rajoidei). Environ. Biol. Fishes 80:221-237. Crossref 
Estrada, M.

1996. Primary production in the northwestern Mediterranean. Sci. Mar. 60(Suppl. 2):55-64.

European Parliament and Council.

2019. Consolidated text: Regulation (EU) No. 1380/2013 of the European Parliament and of the Council of 11 December 2013 on the Common Fisheries Policy, amending Council Regulations (EC) No. 1954/2003 and (EC) No. 1224/2009 and repealing Council Regulations (EC) No. 2371/2002 and (EC) No. 639/2004 and Council Decision 2004/585/EC, 52 p. Publ. Off. Eur. Union, Luxembourg, Luxembourg. [Available from website.]

Fanelli, E., J. E. Cartes, F. Badalamenti, P. Rumolo, and M. Sprovieri. 2009. Trophodynamics of suprabenthic fauna on coastal muddy bottoms of the southern Tyrrhenian Sea (Western Mediterranean). J. Sea Res. 61:174-187. Crossref

Fanelli, E., J. E. Cartes, and V. Papiol.

2011. Food web structure of deep-sea macrozooplankton and micronekton off the Catalan slope: insight from stable isotopes. J. Mar. Syst. 87:79-89. Crossref

Fanelli, E., J. E. Cartes, V. Papiol, and C. López-Pérez.

2013. Environmental drivers of megafaunal assemblage composition and biomass distribution over mainland and insular slopes of the Balearic Basin (Western Mediterranean). Deep-Sea Res., I 78:79-94. Crossref

FAO.

2018. The state of Mediterranean and Black Sea fisheries 2018, 172 p. Gen. Fish. Comm. Mediterr., Rome. [Available from website.]

García, S. M., A. Zerbi, C. Aliaume, T. Do Chi, and G. Lasserre. 2003. The ecosystem approach to fisheries: issues, terminology, principles, institutional foundations, implementation and outlook. FAO Fish. Tech. Pap. 443, 71 p. FAO, Rome. [Available from website.]

García-Rodríguez, M., P. Abelló, A. Fernández, and A. Esteban. 2011. Demersal assemblages on the soft bottoms off the Catalan-Levante coast of the Spanish Mediterranean. J. Mar. Sci. 2011:16. Crossref

García-Rodríguez, E., M. Vivas, M. A. Torres, A. Esteban, J. M. Bellido.

2020. Revealing environmental forcing in the different trophic guilds of fish communities off the Western Mediterranean Sea. J. Sea Res. 166, 101958. Crossref

Gascuel, D.

2005. The trophic-level based model: a theoretical approach of fishing effects on marine ecosystems. Ecol. Model. 189:315-332. Crossref

Guichet, R.

1995. The diet of European hake (Merluccius merluccius) in the northern part of the Bay of Biscay. ICES J. Mar. Sci. 52:21-31. Crossref

Hyslop, E. J.

1980. Stomach contents analysis-a review of methods and their application. J. Fish Biol. 17:411-429. Crossref

Ismen, A., C. C. Yigin, M. A. Ihsanoglu, and M. I. Oz.

2019. Age, growth and reproduction of silvery pout (Gadiculus argenteus Guichenot, 1850) in the Saros Bay (Northeastern Aegean Sea). Thalassas 35:599-605. Crossref

Jaccard, P.

1901. Distribution de la flore alpine dans le Bassin des Drouces et dans quelques régions voisines. Bull. Soc. Vaud. Sci. Nat. 37:241-272. [In French.]

Jacobsen, I. P., and M. B. Bennett.

2013. A comparative analysis of feeding and trophic level ecology in stingrays (Rajiformes; Myliobatoidei) and electric rays (Rajiformes: Torpedinoidei). PLoS ONE 8(8):e71348. Crossref
Juanes, F., J. A. Buckel, and F. S. Scharf.

2002. Feeding ecology of piscivorous fishes. In Handbook of fish biology and fisheries, vol. 1 (P. J.B. Hart and J. D. Reynolds, eds.), p. 267-283. Blackwell Science, Malden, MA.

Karachle, P. K., and K. I. Stergiou.

2017. An update on the feeding habits of fish in the Mediterranean Sea (2002-2015). Mediterr. Mar. Sci. 18:43-52. Crossref

Keast, A.

1978. Trophic and spatial interrelationships in the fish species of an Ontario temperate lake. Environ. Biol. Fishes 3:7-31. Crossref

Levins, $\mathrm{R}$.

1968. Evolution in changing environments: some theoretical explorations, 121 p. Princeton Univ. Press, Princeton, NJ.

Libralato, S., V. Christensen, and D. Pauly.

2006. A method for identifying keystone species in food web models. Ecol. Model. 195:153-171. Crossref

Lombarte, A., Ò. Chic, V. Parisi-Baradad, R. Olivella, J. Riera, E. García-Ladona.

2006. A web-based environment from shape analysis of fish otoliths. The AFORO database. Sci. Mar. 70:147-152. Crossref

López-López, L., V. Bartolino, and I. Preciado.

2015. Role of prey abundance and geographical variables in a demersal top predator's feeding habits (Merluccius merluccius). Mar. Ecol. Prog. Ser. 541:165-177. Crossref

Macpherson, E.

1978a. Régimen alimentario de Micromesistius poutassou (Risso, 1810) y Gadiculus argenteus argenteus Guichenot, 1850 (Pisces, Gadidae) en el Mediterráneo occidental. Invest. Pesq. 42:305-316.

1978b. Régimen alimentario de Phycis blennoides (Brünich) y Antonogadus megalokynodon (Kolombatovic) (Pisces: Gadidae) en el Mediterráneo occidental. Invest. Pesq. 42:455-466.

1979. Estudio sobre las relaciones tróficas en peces bentónicos de la costa catalana. Ph.D. diss., 220 p. [In Spanish.] Univ. Barcelona, Barcelona, Spain. [Available from website.]

1981. Resource partitioning in a Mediterranean demersal fish community. Mar. Ecol. Prog. Ser. 4:183-193. Crossref

Madurell, T., E. Fanelli, and J. E. Cartes.

2008. Isotopic composition of carbon and nitrogen of suprabenthic fauna in the NW Balearic Islands (western Mediterranean). J. Mar. Syst. 71:336-345. Crossref

Marrin, D. L.

1983. Ontogenetic changes and intraspecific resource partitioning in the tahoe sucker, Catostomus tahoensis. Environ. Biol. Fishes 8:39-47. Crossref

McDonald-Madden, E., R. Sabbadin, E. T. Game, P. W. J. Baxter,

I. Chadès, and H. P. Possingham.

2016. Using food-web theory to conserve ecosystems. Nat. Commun. 7:10245. Crossref

Miller, T. W., R. D. Brodeur, G. Rau, and K. Omori.

2010. Prey dominance shapes trophic structure of the northern California Current pelagic food web: evidence from stable isotopes and diet analysis. Mar. Ecol. Prog. Ser. 420:15-26. Crossref

Morisita, M.

1959. Measuring of the dispersion and analysis of distribution patterns. Mem. Fac. Sci., Kyushu Univ., Ser. E, Biol. $2: 215-235$

Morte, M. S., M. J. Redón, and A. Sanz-Brau.

2001. Feeding habits of Trisopterus minutus capelanus (Gadidae) off the eastern coast of Spain (western Mediterranean). Mar. Ecol. 22:215-229. Crossref

2002. Diet of Phycis blennoides (Gadidae) in relation to fish size and season in the western Mediterranean (Spain). Mar. Ecol. 23:141-155. Crossref 
Olaso, I.

1990. Distribución y abundancia del megabentos invertebrado en fondos de la plataforma cantábrica. Inst. Esp. Oceanogr., Publ. Esp. 5, 128 p. [In Spanish.] [Available from Inst. Esp. Oceanogr., Calle Corazón María 8, 28002 Madrid, Spain.]

Paradinas, I., M. Marín, M. G. Pennino, A. López-Quílez, D. Conesa,

D. Barreda, M. Gonzalez, and J. M. Bellido.

2016. Identifying the best fishing-suitable areas under the new European discard ban. ICES J. Mar. Sci. 73:2479-2487. Crossref

Pauly, D., M. L. Palomares, R. Froese, P. Sa-a, M. Vakily,

D. Preikshot, and S. Wallace.

2001. Fishing down Canadian aquatic food webs. Can. J. Fish. Aquat. Sci. 58:51-62. Crossref

Philips, A. E.

2012. Feeding behavior of the European hake Merluccius merluccius Linnaeus, 1758 (Family: Gadidae) from Egyptian Mediterranean waters off Alexandria. Egypt. J. Aquat. Res. 38:39-44. Crossref

Pianka, E. R.

1973. The structure of lizard communities. Annu. Rev. Ecol. Syst. 4:53-74. Crossref

Pinnegar, J. K., S. Jennings, C. M. O’Brien, and N. V. C. Polunin.

2002. Long-term changes in the trophic level of the Celtic Sea fish community and fish market price distribution. J. Appl. Ecol. 39:377-390. Crossref

Preciado, I., J. L. Gutiérrez-Zabala, F. Velasco, and I. Olaso.

2002. Dieta de otoño de once especies de peces demersales en la plataforma Atlántica del sur de Galicia. Nova Acta Cient. Compostel., Biol. 12:125-141.

Preciado, I., F. Velasco, and I. Olaso.

2008. The role of pelagic fish as forage for the demersal fish community in the southern Bay of Biscay. J. Mar. Syst. 72:407-417. Crossref

Robb, A. P.

1992. Changes in the gall bladder of whiting (Merlangius merlangus) in relation to recent feeding history. ICES J. Mar. Sci. 49:431-436. Crossref

Rodríguez-Cabello, C., L. Modica, F. Velasco, F. Sánchez, and I. Olaso. 2014. The role of silvery pout (Gadiculus argenteus) as forage prey in the Galician and Cantabrian Sea ecosystem (NE
Atlantic) in the last two decades. J. Exp. Mar. Biol. Ecol. 461:193-200. Crossref

Rosas-Luis, R., R. Villanueva, and P. Sánchez.

2014. Trophic habits of the Ommastrephid squid Illex coindetii and Todarodes sagittatus in the northwestern Mediterranean Sea. Fish. Res. 152:21-28. Crossref

Scharf, F. S., F. Juanes, and R. A. Rountree.

2000. Predator size-prey size relationships of marine fish predators: interspecific variation and effects of ontogeny and body size on trophic-niche breadth. Mar. Ecol. Prog. Ser. 208:229-248. Crossref

Scherrer, B.

1984. Biostatistique, 850 p. Gaëtan Morin, Montreal, Canada.

Schoener, T. W.

1974. Resource partitioning in ecological communities. Science 185:27-39. Crossref

Silva, M. V., R. H. Morales, and M. M. Nava.

2014. Métodos clásicos para el análisis del contenido estomacal en peces. Biológicas 16(2):13-16.

Tirasin, E. M., and T. Jørgensen.

1999. An evaluation of the precision of diet description. Mar. Ecol. Prog. Ser. 182:243-252. Crossref

Torres, M. A., M. Coll, J. J. Heymans, V. Christensen, and I. Sobrino.

2013. Food-web structure of and fishing impacts on the Gulf of Cadiz ecosystem (South-western Spain). Ecol. Model. 265:26-44. Crossref

Trites, A. W.

2003. Food webs in the ocean: who eats whom and how much? In Responsible fisheries in the marine ecosystem (M. Sinclair and G. Valdimarsson, eds.), p. 125-141. FAO, Rome.

Velasco, F., and I. Olaso.

1998. European hake Merluccius merluccius (L., 1758) feeding in the Cantabrian Sea: seasonal, bathymetric and length variations. Fish. Res. 38:33-44. Crossref

Zariquiey Alvarez, R.

1968. Crustáceos decápodos ibéricos. Investig. Pesq., vol. 32, 510 p. Inst. Inv. Pesq., Barcelona, Spain. 